Journal of Tropical Resources and Sustainable Science

journal homepage: jtrss.org

\title{
Assessment of potable groundwater quality and it's impact on human health: a case study from Sylhet Region, Bangladesh
}

\author{
Sameena Begum ${ }^{1}$, Tasfia Shahid ${ }^{1}$, Md. Asraf Uddin ${ }^{2 * *}$, Md. Shohel Khan ${ }^{3}$, Zia Ahmed ${ }^{1}$, Syeda Ayshia Akter ${ }^{1}$ and \\ Md. Tariqul Islam ${ }^{1}$ \\ ${ }^{1}$ Department of Geography and Environment, Shahjalal University of Science and Technology Sylhet-3114, Bangladesh. \\ ${ }^{2}$ Department of Geography and Environment, Jagannath University, Dhaka-1100, Bangladesh. \\ ${ }^{3}$ Faculty of Science, Department of Environmental Science and Disaster Management, Noakhali Science and Technology University, \\ Noakhali-3814, Bangladesh.
}

Received 15 February 2019

Accepted 19 April 2019

Online 31 December 2019

Keywords:

Groundwater quality, potable water, human health, permissible limit and concentrations

\*Correspondence: Assistant Professor, Faculty of Science, Department of Environmental Science and Disaster Management, Noakhali Science and Technology University, Noakhali-3814, Bangladesh. E-mail: sajibicb@gmail.com

\begin{abstract}
Potable groundwater is the main source of drinking water in Bangladesh. It is continuously polluted by different pollutants and making negative impact on human health. The objectives of this research were to determine the portable water quality and comparison with the standard set by Department of Environment (DoE, 1997), Bangladesh and World Health Organization (WHO, 2011) for assessing the suitability of consumption. A total of 51 groundwater samples was collected from 17 sampling stations at Companiganj Upazila of Sylhet District to analyze $\mathrm{p}^{\mathrm{H}}$, iron $(\mathrm{Fe})$, Total Dissolved Solids (TDS) and Total Suspended Solid (TSS). A semi-structured questionnaire survey with 320 purposively selected respondents were conducted to know the people's perception on human health impacts of ground water. The results revealed that $\mathrm{p}^{\mathrm{H}}$ values of all stations were within the permissible limit set by DoE and WHO and the range of concentration of Fe, TDS and TSS were $0.3-1.0 \mathrm{mgl}^{-1}, 220-2870 \mathrm{mgl}^{-1}$ and $10-1900 \mathrm{mgl}^{-1}$, respectively. $58.82 \%$ sampling stations were found very high contamination of Fe and TDS followed by medium $11.76 \%$ and $23.53 \%$. The TSS values indicated that $11.76 \%$ sampling stations had excellent water, while $88.24 \%$ had high level of pollution expressed as unacceptable for drinking purposes. The results indicated that $40 \%$ respondents were suffered from skin diseases and followed by hair fall (33.9\%) and nail damage (26.1\%), respectively. $76.47 \%$ groundwater samples extremely contaminated with TDS (>1000 $\mathrm{mgl}^{-1}$ ) and this might be indicated that peoples were susceptible to hypertension or blood pressure, gastro-intestinal irritation and cardiovascular disease. Contaminated groundwater were consumed without any purification process, filtering or treatment because of these system were costly for the poor and ultra-poor. So, they prefer to consume contaminated water without any treatment.
\end{abstract}

(C) 2019 UMK Publisher. All rights reserved.

\section{INTRODUCTION}

Potable groundwater is the principal source of safe drinking water in Bangladesh. But, now-a-days and much of it highly polluted with various physiochemical elements and toxic heavy metals (Hassan et al., 2006). During the recent time sustainable groundwater resources management strategies is essential for developing countries for reduction of health risks form the toxicity of heavy metals and physiochemical elements. Because, there remain scarcity of fresh water and groundwater contamination with toxic heavy metals and these create various health hazards. Most importantly, sustainable potable groundwater quality management strategies are not only needed at national level but also all around the world for drinking, agriculture irrigation system and domestic purposes (Bodrud-Doza et al., 2016). It is ironic that so many tube-wells were installed in Bangladesh during the recent times for pathogen-free drinking water, but water is now polluted with toxic levels of physiochemical elements and heavy metals (Hassan et al., 2003).

In developing countries like Bangladesh, highly contaminated groundwater quality create human health tragedy, resulting in millions of deaths each year, preventing millions more from leading healthy lives, and undermining development efforts by burdening the society with substantial socio-economic costs (El-Fadel et al., 2003). The northeastern part of Bangladesh is highly susceptible to contaminated groundwater due to morphdynamics of river basin, lake of water resources management strategies, intensive agriculture practice with toxic chemical fertilizer and insecticides, industrial chemical effluents, tropical climatic variability and human intervention. This scenario concerns poor and ultra-people lives owing highly contaminated physiochemical elements and heavy metals toxicity and this situation become more worsened due to their existing poor ground water supply 
systems, poverty, financial crisis and inadequate natural resources. Moreover, heavy metals particularly Iron $(\mathrm{Fe})$ is common to potable groundwater and the prominent concentrations of this metal has been a long deep concern because of the potential adverse effects on human health and the aesthetic or nuisance problems that some present in the Sylhet district of northeastern Bangladesh (Islam et al., 2017). Evaluation of potable groundwater quality closely accompanying with health status or health risk from a certain place. During the recent time, to ensure safe and pathogen free groundwater among the rural community for drinking purpose; suitable methodologies, tools and techniques are essential for evaluation groundwater quality.

Groundwater quality analysis carried out through various cafeteria using different tools and techniques to find out the multiple scopes, including (i) mapping spatial variability, pattern and distribution of groundwater heavy metals concentration using geostatistical approaches (Shi, et al 2007; Hassan and Atkins, 2011; Gorai and Kumar 2013), (ii) characterization of groundwater quality using water evaluation indices, multivariate statistics, geostatistical techniques (Backman et al., 1998; Prasad and Bose, 2001; Edet and Offiong, 2002; Farnham et al., 2003; Yongming, et al., 2006; Adhikary, et al., 2010; Masoud, 2014; Tiwari et al., 2014; Bhuiyan, et al 2016; BodrudDoza, 2016; Islam 2017a) for suitability analysis of drinking water, agriculture irrigation systems and industrial uses (Doneen, et al., 1964; Zaman et al 2001, Sarkar and Hassan, 2006; Islam et al., 2009; Hassen, et al 2016; Aksever, et al., 2016; Islam, et al., 2017a; Rahman et al., 2017), (iii) showing the impacts of groundwater contamination on human health (Islam, 2015). Groundwater contamination with toxic elements for drinking purpose is susceptible to health risks of human. The $\mathrm{pH}$ was ranged to $4.67 \pm 0.13 \mathrm{mgl}^{-1}$ in Asian countries of the world (Salam, et.al. 2019). Thus, it is essential to evaluate groundwater quality and its suitability for drinking purpose that reduce the health risk. Potable groundwater quality for drinking purpose is a complex process that needed numerous heavy metals and physiochemical elements those are able to contaminate and degrade potable groundwater quality which could be unsuitable for drinking purpose.

The objectives of this research were to compare the quality of potable water with Department of Environment (DoE, 1997) and World Health Organization (WHO, 2011) standards and identified the human health impacts associated with it. For this, person's correlation matrix was used to identify underlying causes or origin of groundwater pollution; geo-statistical modeling particularly inverse distance weighting (IDW) modeling was applied to spatial susceptibility of groundwater contamination mapping at West Islampur Union of Companiganj Upazila, Sylhet.

\section{MATERIALS AND METHODS \\ 2.1 Study Area}

West Islampur Union of Companiganj Upazila is located in the northeastern tertiary hilly region of Bangladesh lies between $25.07^{\circ}$ to $25.16^{\circ} \mathrm{N}$ latitude and $91.71^{\circ}$ to $92.78^{\circ} \mathrm{E}$ longitude covering with small area of $32.95 \mathrm{~km}^{2}$ (Fig. 1). The landscape topography of this region characterized asymmetrical configuration. The topographic elevation of this region is about $33.5 \mathrm{~m}$ above the mean sea level (MLS) and geomorphic features consists of shallow depression and slightly higher ridges. Land use and land cover (LULC) comprises of 74.52\% (24.55 $\left.\mathrm{km}^{2}\right)$ agricultural land, 17.26\% (5.69 $\left.\mathrm{km}^{2}\right)$ rural settlements with homestead vegetation, $6.59 \%\left(2.17 \mathrm{~km}^{2}\right)$ water bodies, $0.62 \%\left(0.20 \mathrm{~km}^{2}\right)$ road, $0.49 \%\left(0.16 \mathrm{~km}^{2}\right)$ mining area, $0.39 \%\left(0.13 \mathrm{~km}^{2}\right)$ char land/sand, $0.05 \%$ $\left(0.02 \mathrm{~km}^{2}\right)$ urban built-up area and $0.07 \%\left(0.02 \mathrm{~km}^{2}\right)$ forest land, respectively (Fig. 1). This area influenced by subtropical humid climate (e.g. hot summer and cold winter), where exist $25^{\circ} \mathrm{C}$ mean annual temperature (Islam et al., 2017), rainfall ranging from 3000 to $5000 \mathrm{~mm}$ per year and more than $80 \%$ rainfall experience in the month of June to September (Munna et al., 2015). Due to geographical location of tertiary hilly northeastern region and tropical monsoon wind movement flows Bay of Bengal to Cherrapunji (sub-divisional town in the East Khasi Hills district in the Indian state of Meghalaya). Surma Basin floodplain study area groundwater discharge, water and sediment transport controlled by numerous rills, gullies and streams of Indian Meghalaya State piedmont hills. The principal source of drinking water of this region is groundwater which is accessible in the shallow and deep aquifer and can be extract through shallow and deep wells. In this study area, people's livelihood patterns are agricultural activities, stone collection and stone business.

\subsection{Groundwater Sample Collection}

Groundwater samples were collected from March to April, 2018 from 17 sampling sites of Parua Bazar, Shah Arfin Bazar and Bholaganj Bazar at West Islampur Union, Companiganj, Sylhet District of Bangladesh. Global Positioning System (GPS) (Magellan eXplorist 510, model no. TX0510SGXNA) is used to identify the absolute sample location of each pumping well of the study area. After collecting water samples, all of these were carefully labeled with white colored tape and numbered prior to transport and kept at low temperature $\left(\leq 4^{\circ} \mathrm{C}\right)$. These were preserved in the Environmental Lab of the Department of Geography and Environment, Shahjalal University of Science and Technology (SUST) for testing. These were preserved by using carbon paper.

\subsection{Questionnaire survey}

A structured questionnaire survey was conducted between December 2017-March 2018 from three selected areas (Parua Bazar, Shah Arfin Bazar and Bholaganj Bazar) of the study region.

\subsection{Laboratory analytical procedure}

The $\mathrm{p}^{\mathrm{H}}$ of all groundwater samples were measured by using digital $\mathrm{p}^{\mathrm{H}}$ meter (Hana $\mathrm{p}^{\mathrm{H}}$ meter, model no. HI2211). Total Dissolved Solids (TDS) and Total Suspended Solid (TSS) were measured by Filtration Method (Standard Methods by APHA, 1998) whereas Iron (Fe) concentration was measured by using UV spectrophotometer. 


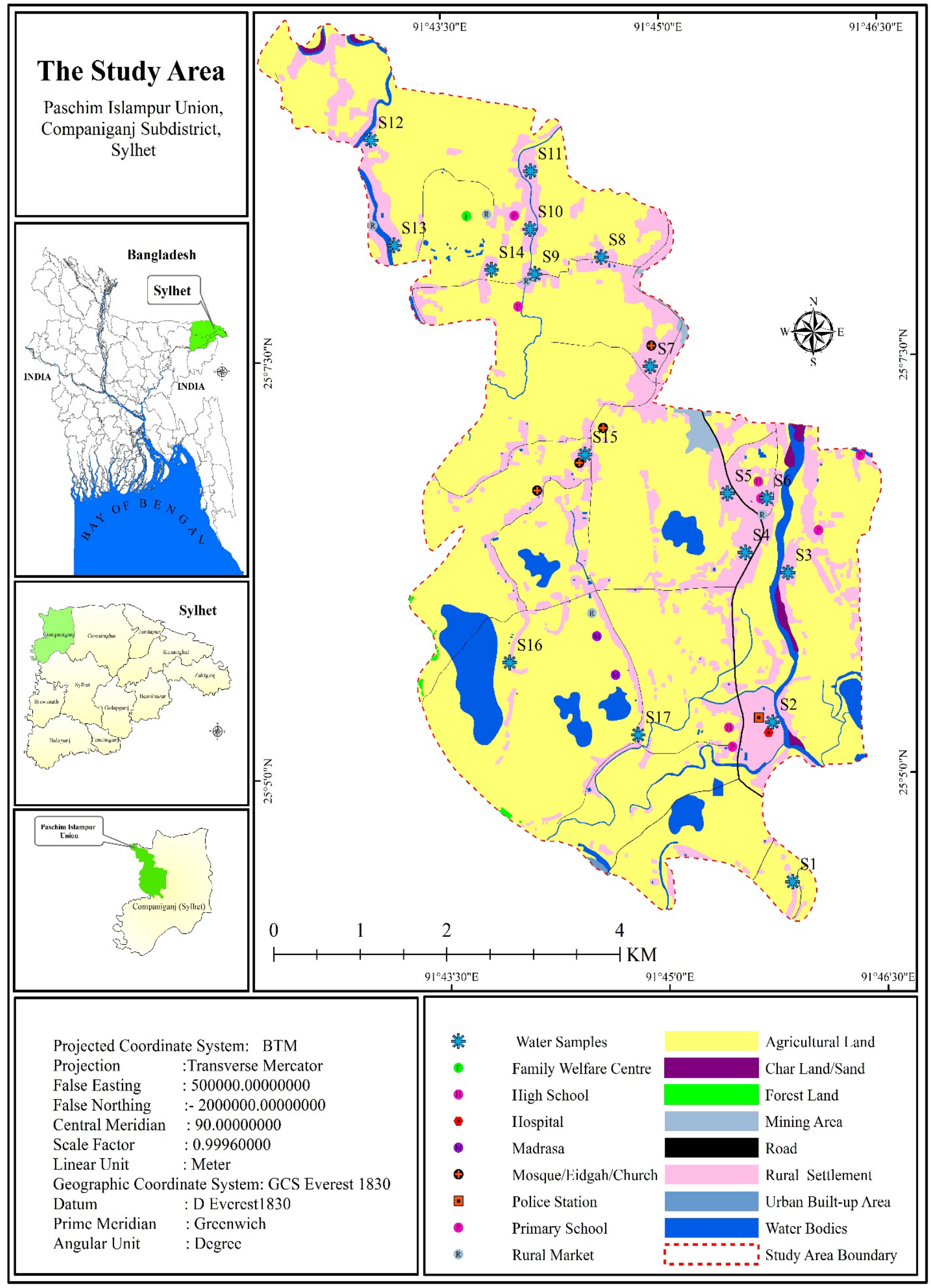

Figure 1: Location of the study area and sampling stations

Table 1: Potable groundwater analysis results of selected parameters in the study area 
J. Trop. Resour. Sustain. Sci. 7 (2019): 69-76

\begin{tabular}{cccccccc}
\hline $\begin{array}{c}\text { Sample } \\
\text { St. No. }\end{array}$ & $\begin{array}{c}\text { Geographical Location } \\
\text { Latitude }\end{array}$ & Longitude & $\begin{array}{c}\text { Depth } \\
\text { (Feet) }\end{array}$ & pH & Fe (mg/L) & $\begin{array}{c}\text { Parameters } \\
\text { TDS (mg/L) }\end{array}$ & TSS (mg/L) \\
\hline 1 & $91.7642^{\circ} \mathrm{N}$ & $25.0726^{\circ} \mathrm{E}$ & 25 & 6 & 0.5 & 2710 & 290 \\
2 & $91.7621^{\circ} \mathrm{N}$ & $25.0885^{\circ} \mathrm{E}$ & 18 & 6 & 0.8 & 1290 & 120 \\
3 & $91.7640^{\circ} \mathrm{N}$ & $25.1034^{\circ} \mathrm{E}$ & 20 & 7 & 0.5 & 1940 & 30 \\
4 & $91.7592^{\circ} \mathrm{N}$ & $25.1055^{\circ} \mathrm{E}$ & 20 & 6 & 0.5 & 2670 & 10 \\
5 & $91.7572^{\circ} \mathrm{N}$ & $25.1114^{\circ} \mathrm{E}$ & 18 & 6 & 0.7 & 1050 & 260 \\
6 & $91.7617^{\circ} \mathrm{N}$ & $25.1109^{\circ} \mathrm{E}$ & 55 & 7 & 0.3 & 220 & 20 \\
7 & $91.7486^{\circ} \mathrm{N}$ & $25.1242^{\circ} \mathrm{E}$ & 23 & 7 & 0.3 & 670 & 10 \\
8 & $91.7431^{\circ} \mathrm{N}$ & $25.1351^{\circ} \mathrm{E}$ & 35 & 7 & 0.4 & 460 & 220 \\
9 & $91.7355^{\circ} \mathrm{N}$ & $25.1335^{\circ} \mathrm{E}$ & 30 & 7 & 0.5 & 1790 & 180 \\
10 & $91.7350^{\circ} \mathrm{N}$ & $25.1380^{\circ} \mathrm{E}$ & 25 & 6 & 0.7 & 680 & 120 \\
11 & $91.7351^{\circ} \mathrm{N}$ & $25.1438^{\circ} \mathrm{E}$ & 20 & 6 & 0.7 & 1710 & 150 \\
12 & $91.7169^{\circ} \mathrm{N}$ & $25.1471^{\circ} \mathrm{E}$ & 20 & 6 & 0.7 & 2670 & 220 \\
13 & $91.7194^{\circ} \mathrm{N}$ & $25.1366^{\circ} \mathrm{E}$ & 29 & 6 & 0.8 & 760 & 90 \\
14 & $91.7305^{\circ} \mathrm{N}$ & $25.1340^{\circ} \mathrm{E}$ & 18 & 6 & 0.8 & 1270 & 1900 \\
15 & $91.7410^{\circ} \mathrm{N}$ & $25.1155^{\circ} \mathrm{E}$ & 18 & 6 & 1 & 1060 & 1700 \\
16 & $91.7320^{\circ} \mathrm{N}$ & $25.0948^{\circ} \mathrm{E}$ & 18 & 6 & 1 & 2130 & 90 \\
17 & $91.7467^{\circ} \mathrm{N}$ & $25.0874^{\circ} \mathrm{E}$ & 25 & 6 & 0.7 & 2870 & 10 \\
\hline
\end{tabular}

Inverse distance weighting (IDW) modeling for spatial susceptibility

Inverse Distance Weighting (IDW) modeling is applied for spatial susceptibility of physiochemical elements and heavy metal contamination intensity which is associated with the groundwater resources management strategies in applied hydrochemistry analysis. This model have significant implication in groundwater resources management for drinking purpose and mitigation health hazard spatial vulnerability, that is well reported in the most recent literatures (e.g., Kumari et al. 2014; Ağca et al. 2014; Bhuiyan et al. 2016; Islam et al., 2017 b). For spatial susceptibility mapping and prediction of groundwater toxicity of physiochemical elements and heavy metals, using inverse distance weighting (IDW) model where the weight $\left(\lambda_{\mathrm{i}}\right)$ depends on the distance to the predicted location. In this (IDW) model, the weights are constructed on the distance between the groundwater sample location and the prediction location points as well as the overall spatial auto correlation to compare with other geostatistical models. The weighting is controlled by the power of weights, such that if the power is greater the effect of the points to the distance is greater than expected (Goovaerts, 2000). In this model, the weighted value $\left(\lambda_{\mathrm{i}}\right)$ of groundwater variables decreases with increasing distance from the prediction point and it is calculated through the $\left(\lambda_{i}=d_{i 0}^{-p} / \sum_{i=1}^{n} d_{i 0}^{-p}\right)$ formula. Where, $\mathrm{d}_{\mathrm{i} 0}$ denotes the distance between the groundwater sample locations and the prediction points. For instance, when the distance becomes larger, the weight is reduced exponentially by a power parameter of p. Therefore, the IDW model produces a relatively rough surface, which is dependent on the distance between sample points (Burrough and McDonnell, 1998).

\section{RESULTS AND DISCUSSION}

\subsection{Statistics and sources of pollution}

Physiochemical parameters of potable groundwater descriptive statistics (minimum, maximum, mean and standard deviation) in the study area were summarized in Table 2. Chemical analysis results from all the sampling stations $(n=17)$ revealed that the $\mathrm{p}^{\mathrm{H}}$ values vacillated from 6 to 6.9 with the mean value of 6.37 and standard deviation \pm 0.24 , representing acidic to slight basic solution nature. Moreover, the $\mathrm{p}^{\mathrm{H}}$ nature and the trend of the analysis were consistent with the study findings of Rahman et al. (2014), they assessed the quality of groundwater in the northwestern part of Bangladesh and found $\mathrm{p}^{\mathrm{H}}$ acidic to little alkaline nature. On the other hand, the heavy metal Fe concentration in potable groundwater in the study area ranged from $0.3 \mathrm{mg} / \mathrm{L}$ to $1 \mathrm{mg} / \mathrm{L}$ with a mean value of 0.64 and standard deviation of \pm 0.21 . The variation and high concentration of $\mathrm{Fe}$ in the sampling stations of the study area were found to tropical climate, in where excessive rainfall comes in contact with ozone $\left(\mathrm{O}_{3}\right)$ of the atmosphere and transformed iron-oxidized to the ferric $\left(\mathrm{FeO}, \mathrm{Fe}_{2} \mathrm{O}_{3}\right)$ state and infiltrated earth surface to groundwater level. The concentration of TDS and TSS in the study area varied from ranged 220 to $2827 \mathrm{mg} / \mathrm{L}$ and 10 to $1900 \mathrm{mg} / \mathrm{L}$ with the mean values of $1526.47 \pm 836.92$ and $318.82 \mathrm{mg} / \mathrm{l} \pm 546.9$, respectively.

\subsection{Comparison of potable groundwater quality with DoE and WHO standards}

The quality of the potable groundwater samples in the study area were compared with DoE (1997) and WHO (2011) standards for the purpose of suitability analysis of drinking water. The result revealed that $\mathrm{p}^{\mathrm{H}}$ values of all the sampling stations along with their mean values (6.37 \pm 0.24 ) were in the permissible limits for drinking water suitability set by DoE (1997), but 29.41\% water samples exceeds lower limits set by the standard of WHO (2011). For Fe concentrations, $88.24 \%$ potable groundwater samples mean values $(0.64)$ were higher than the limits set by WHO, but according to DoE, the concentration of all the sampling stations were within the permissible limit for 
J. Trop. Resour. Sustain. Sci. 7 (2019): 69-76

drinking purpose. The concentration of TDS excides the permissible limits for drinking water suitability and these were $88.24 \%$ and $70.59 \%$ stations in the study area all the potable groundwater sampling stations showed high concentration of TSS in the study area which exceeds both permitted by WHO and DoE, respectively. It is found that

Table 2: Statistics of potable groundwater parameters in the study area

\begin{tabular}{|c|c|c|c|c|c|c|}
\hline \multirow{2}{*}{ Parameter } & \multirow{2}{*}{ Minimum } & \multirow{2}{*}{ Maximum } & \multirow{2}{*}{ Mean } & \multirow{2}{*}{ Std. deviation } & \multicolumn{2}{|c|}{ Standard } \\
\hline & & & & & WHO (2011) & DoE (1997) \\
\hline $\mathrm{p}^{\mathrm{H}}$ & 6 & 6.9 & 6.37 & 0.24 & $6.4-7.5$ & 8.5 \\
\hline $\mathrm{Fe}(\mathrm{mg} / \mathrm{L})$ & 0.3 & 1 & 0.64 & 0.21 & 03 & $0.3-1.0$ \\
\hline TDS (mg/L) & 220 & 2827 & 1526.47 & 836.92 & 500 & 1000 \\
\hline TSS (mg/L) & 10 & 1900 & 318.82 & 546.9 & 10 & 10 \\
\hline
\end{tabular}

Table 3: Parameters of groundwater quality for drinking purpose in the study area

\begin{tabular}{|c|c|c|c|c|c|}
\hline Parameter & Category & Suitability Status & $\begin{array}{l}\text { Number of } \\
\text { Station (S) }\end{array}$ & S \% & Stations \\
\hline \multirow{3}{*}{$\mathrm{p}^{\mathrm{H}}$} & $6.4-7.5$ & Excellent Water & 17 & 100 & S1-S17 \\
\hline & 7.6-8.5 & Good Water & 0 & 0 & - \\
\hline & $<6.4$ and $>8.5$ & Very Poor water & 0 & 0 & - \\
\hline \multirow{3}{*}{$\mathrm{Fe}(\mathrm{mg} / \mathrm{L})$} & $0.3-4$ & Excellent Water & 3 & 17.65 & S6-S8 \\
\hline & $0.5-10$ & Good Water & 4 & 23.53 & S1, S3, S4, S9 \\
\hline & $<0.3$ and $>10$ & Very Poor water & 10 & 58.82 & S2,S5, S10-S17 \\
\hline \multirow{4}{*}{ TDS (mg/L) } & $50-150$ & Excellent Water & 0 & 0 & - \\
\hline & $151-500$ & Good Water & 2 & 11.76 & S6, s9 \\
\hline & $501-2000$ & Poor water & 10 & 58.82 & S2, S3, S5, S7, S9-S11, S13-S15 \\
\hline & $<50$ and $>2000$ & Very Poor water & 5 & 29.41 & S1, S4, S16, S17, \\
\hline \multirow{2}{*}{ TSS (mg/L) } & 10 & Excellent Water & 2 & 11.76 & S7,S17 \\
\hline & $>10$ & Very Poor water & 15 & 88.24 & S1-S6, S8-S16 \\
\hline
\end{tabular}

3.3 Potable groundwater pollution status for drinking water suitability analysis

Potable groundwater pollution status in the study area were categorized with proposed criteria for suitability of drinking water purpose and summarized in Table 3. In the proposed criteria $\mathrm{p}^{\mathrm{H}}$ for groundwater were thus categorized: excellent water $\left(\mathrm{p}^{\mathrm{H}}\right.$ : 6.4-7.5), good water $\left(\left(\mathrm{p}^{\mathrm{H}}\right.\right.$ : 7.6-8.5), and poor water $\left(\left(\mathrm{p}^{\mathrm{H}}:<6.4 \&>8.5\right)\right.$. The classification criteria also indicated level of pollution status for drinking ground water. The excellent, good, poor and very poor water indicated low, medium, high and very high level contamination in groundwater, respectively. The $\mathrm{p}^{\mathrm{H}}$ values of all sampling stations indicated low level of pollution. But, dissimilar results were observed in Fe contamination of $58.82 \%$ sampling stations with very high level pollution those were not suitable for drinking purposes. Moreover, in the study area TDS concentration analysis results revealed that there was almost no excellent water for drinking, where $11.76 \%$ and $58.82 \%$ sampling stations with medium and high level of pollution. The TSS values indicated that $11.76 \%$ groundwater sampling stations had excellent water, while $88.24 \%$ sampling stations had high level of pollution expressed as unacceptable for drinking purposes in the study area.

Table 4: Correlation matrix among the potable groundwater parameters

\begin{tabular}{|c|c|c|c|c|}
\hline & $\mathrm{pH}$ & $\mathrm{Fe}(\mathrm{mg} / \mathrm{l})$ & TDS (mg/l) & TSS (mg/l) \\
\hline $\mathrm{pH}$ & 1 & & & \\
\hline $\mathrm{Fe}(\mathrm{mg} / \mathrm{l})$ & $-0.91^{* *}$ & 1 & & \\
\hline $\mathrm{TDS}(\mathrm{mg} / \mathrm{l})$ & $-0.38^{*}$ & 0.17 & 1 & \\
\hline TSS (mg/l) & $-0.40^{* *}$ & $0.46^{* *}$ & -0.14 & 1 \\
\hline
\end{tabular}

*Correlation is significant at the 0.05 level (2-tailed) ${ }^{* *}$ Correlation is significant at the 0.01 level (2-tailed)

\subsection{Correlation matrix analysis}

Potable groundwater heavy metal and physiochemical elements interrelationship and coherence pattern carried out through Pearson's correlation coefficient equation. The results (table 4) revealed that a strongly negative correlation $(\mathrm{r}=-0.91)$ between $\mathrm{Fe}$ : $\mathrm{pH}$, negative correlation $(r=-0.40)$ between $\mathrm{pH}$ : TSS, positive correlation $(\mathrm{r}=0.46)$ between Fe: TSS, weak positive correlation $(r=0.17)$ between Fe: TDS with 95\% confidence level whereas negative correlation $(r=-0.38)$ between pH: TDS with 99\% confidence level. These correlation matrix analysis results designated that mixed sources of groundwater pollution, which may be either climatic variability or even anthropogenic origin. These 
J. Trop. Resour. Sustain. Sci. 7 (2019): 69-76

indicated that physico-chemical parameters had also mix sources of origin, which may be the results from the morpho-dynamics of Surma Basin by sedimentation process through numerous streams of Indian Meghalaya State piedmont hills, extensive agriculture practice with chemical fertilizer and insecticides in Surma Basin flood plain by local communities and excessive rainfall due to geographical location.

\subsection{Spatial susceptibility of groundwater contamination}

Groundwater $\quad \mathrm{p}^{\mathrm{H}} \quad$ concentrations spatial susceptibility map indicated that high concentration were observed in northeastern side of the study area, while low level of concentrations were found southwestern part of West Islampur Union of Companiganj Upazila at Sylhet District in Bangladesh (Fig. 2). Moreover, the spatial susceptibility of Fe concentration demonstrated that an increasing trend in the northeastern to southwestern direction, which advocated the presence of analogous sources of pollutants of groundwater contamination. On the other hand, the spatial susceptibility TDS concentration exhibited a complex pattern in the study area. High concentration of TDS found in north and southeastern part of the study area. This scenario are the resulted from the haphazard and hysterical groundwater extractions for domestic purpose and irrigation in agriculture system. The spatial susceptibility of TSS concentration revealed that high level of concentration found in central part of the study area and decreasing trend initiated from central part to the north and south direction. Groundwater could be contaminated due to dissolve sediments and suspend solids washed away from Indian Meghalaya State piedmont hills through different streams and deposited in the Surma basin, leaching of heavy metal ions from excessive rain water interaction through weathering process, extraction of boulder and sediment from tertiary hills and river bed for the livelihood by poor and ultra-poor local people, the haphazard domestic sewage dumping due to over population and extensive agriculture practices with toxic chemical fertilizer and insecticides.
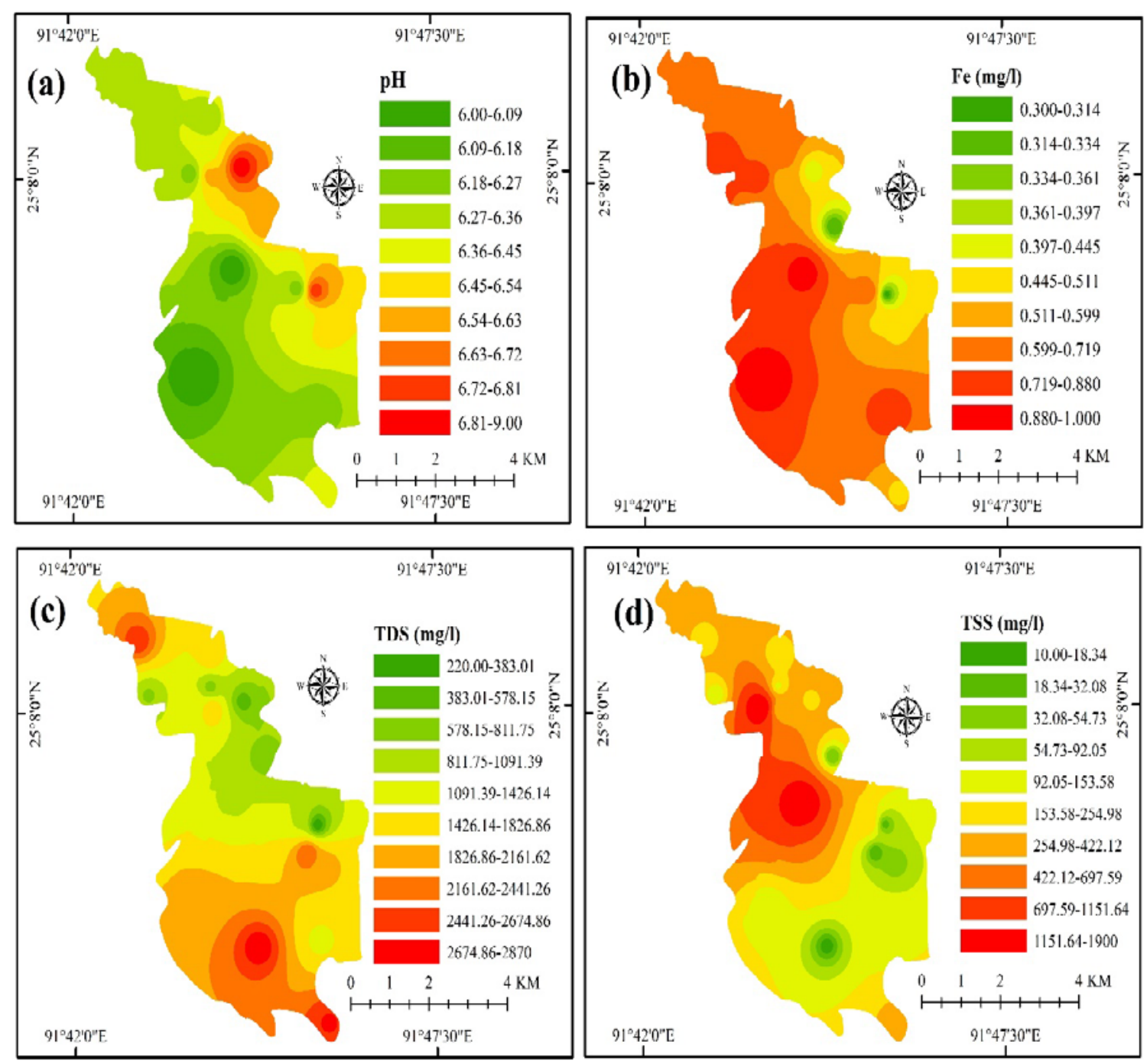

Figure 2: Spatial susceptibility of groundwater contamination 


\section{6}

\section{Risks of health hazard}

Long term exposures of polluted groundwater with high level of toxic heavy metals and physiochemical elements create numerous health hazards. The long term effect on human health of toxic heavy metals and other physiochemical elements were skin cancer, kidney damage, liver damage and lunch cancer. Peoples in the study area are suffering from various external diseases (e. g. skin diseases, hair fall and nail damage) and internal diseases (e. g. liver damage, joint pain, stomach pain, heart diseases and cancer) due to excess iron ( $\mathrm{Fe}$ ) intake and iron (Fe) over load acknowledge by the respondents. According to the questionnaire survey results, $40 \%$ respondents were suffered from skin diseases and followed by $33.9 \%$ and $26.1 \%$ were hair fall and nail damage respectively. Moreover, in the study area, $76.47 \%$ groundwater samples extremely contaminated with TDS (>1000 mg/L) and this may be indicated that peoples were susceptible to hypertension or blood pressure, gastro-intestinal irritation and cardiovascular disease. Only $11.76 \%$ samples were standard level of TDS $(<1000 \mathrm{mg} / \mathrm{L})$ that was usually acceptable to the consumer, while $11.76 \%$ samples were low level of TDS $(<500 \mathrm{mg} / \mathrm{L})$ those are unacceptable because of fat, rich nutrient and insipid taste. Furthermore, 88.24\% groundwater samples contaminated with high level of TSS $(>10 \mathrm{mg} / \mathrm{L})$ and this result indicated that peoples in the study area are susceptible to incidence of cancer, coronary heart disease, arteriosclerotic heart disease and cardiovascular disease. Generally, in the rural areas of Bangladesh, particularly in the study area, contaminated groundwater used for drinking purpose without flowing any purification process, filtering or treatment, as these purification systems are costly for the poor and ultra-poor rural communities thus they prefers to intake contaminated and nutrient rich groundwater without any treatment.

\section{CONCLUSION}

In this study, sources of groundwater pollution were determined using Pearson's correlation coefficient and spatial susceptibility of the groundwater contamination mapping by Inverse Distance Weighting (IDW) of Geostatistical modeling in the West Islampur Union of Companiganj, Sylhet in Bangladesh. It is cleared that, quantity of water used by a person fluctuates from 25-30 L (47.2\%) and 20-25 L (52.8\%). Analysis results revealed that $\mathrm{pH}$ values from all sampling stations indicated low level of pollution but dissimilar results were observed in $\mathrm{Fe}$ contamination with $58.82 \%$ sampling stations were very high level pollution those were unsuitable for drinking. The study also resulted that people in the study area susceptible to incidence of cancer, coronary heart disease, arteriosclerotic heart disease, and cardiovascular disease, hypertension or blood pressure, gastro-intestinal irritation. Thus, pure drinking groundwater with standard $\mathrm{pH}, \mathrm{Fe}$, TDS and TSS parameters should be assured in the study area in order to reduce human health risk in the long run.

\section{ACKNOWLEDGEMENT}

The authors acknowledge the local respondents and leaders who willingly agreed to take part in the interview and provide information for this research work. The authors also acknowledge the Department of Geography and Environment of Shahjalal University of Science and Technology for providing laboratory support to accomplish the research.

\section{REFERENCES}

Adhikary, P.P., Chandrasekharan, H., Chakraborty, D. and Kamble, K., (2010). Assessment of groundwater pollution in West Delhi, India using geostatistical approach. Environmental Monitoring and Assessment, 167(1-4), pp.599-615.

Ağca, N., Karanlık, S. and Ödemiş, B., (2014). Assessment of ammonium, nitrate, phosphate, and heavy metal pollution in groundwater from Amik Plain, southern Turkey. Environmental monitoring and assessment, 186(9), pp.5921-5934.

Aksever, F., Davraz, A. and Bal, Y., (2016). Assessment of water quality for drinking and irrigation purposes: a case study of Başköy springs (Ağlasun/Burdur/Turkey). Arabian Journal of Geosciences, 9(20), p.748.

APHA, (1998). Standard Methods for the Examination of Water and Waste Water. American Public Health Association, Washington, DC.

Backman, B., Bodiš, D., Lahermo, P., Rapant, S. and Tarvainen, T., (1998). Application of a groundwater contamination index in Finland and Slovakia. Environmental Geology, 36(1-2), pp.55-64.

Bhuiyan, M.A.H., Bodrud-Doza, M., Islam, A.T., Rakib, M.A., Rahman, M.S. and Ramanathan, A.L., (2016). Assessment of groundwater quality of Lakshimpur district of Bangladesh using water quality indices, geostatistical methods, and multivariate analysis. Environmental Earth Sciences, 75(12), p.1020.

Bodrud-Doza, M., Islam, A.T., Ahmed, F., Das, S., Saha, N. and Rahman, M.S., (2016). Characterization of groundwater quality using water evaluation indices, multivariate statistics and geostatistics in central Bangladesh. Water Science, 30(1), pp.19-40.

Burrough, P. and McDonnell, R., (1998). Spatial Information Systems and Geostatistics. P. Burrough, \& R. McDonnell, Principles of Geographical Information Systems, 333.

DoE., (1997). The environment conservation rules 1997. Dhaka: Government of the People's Republic of Bangladesh.

Doneen, L.D., (1964). Notes on water quality in agriculture, Water Science and Engineering Paper 4001, Dept. of Water. Science and Engineering, Univ. of California, Davis, USA.

Edet, A.E. and Offiong, O.E., (2002). Evaluation of water quality pollution indices for heavy metal contamination monitoring. A study case from Akpabuyo-Odukpani area, Lower Cross River Basin (southeastern Nigeria). GeoJournal, 57(4), pp.295-304.

El-Fadel, M., Maroun, R., Semerjian, L. and Harajli, H., (2003). A healthbased socio-economic assessment of drinking water quality: the case of Lebanon. Management of Environmental Quality: An International Journal, 14(3), pp.353-368.

Farnham, I.M., Johannesson, K.H., Singh, A.K., Hodge, V.F. and Stetzenbach, K.J., (2003). Factor analytical approaches for evaluating groundwater trace element chemistry data. Analytica Chimica Acta, 490(1-2), pp.123-138.

Goovaerts, P., (2000). Geostatistical approaches for incorporating elevation into the spatial interpolation of rainfall. Journal of hydrology, 228(1-2), pp.113-129.

Gorai, A.K. and Kumar, S., (2013). Spatial distribution analysis of groundwater quality index using GIS: a case study of Ranchi Municipal Corporation (RMC) area. Geoinform Geostat Overv, 1, p.2.

Hassan, M.M. and Atkins, P.J., (2011). Application of geostatistics with indicator kriging for analyzing spatial variability of groundwater arsenic concentrations in Southwest Bangladesh. Journal of Environmental Science and Health, Part A, 46(11), pp.1185-1196.

Hassan, M. M., Atkins, P.J. and Dunn, C.E., (2003). The spatial pattern of risk from arsenic poisoning: a Bangladesh case study. Journal of Environmental Science and Health, Part A, 38(1), pp.1-24. 
J. Trop. Resour. Sustain. Sci. 7 (2019): 69-76

Hassan, M.M., Atkins, P.J. and Dunn, C.E., (2006). Pattern of Groundwater Arsenic Concentrations: What Level of Arsenic Exists in Different Aquifers? Oriental Geographer, 50(2), pp.1-17.

Hassen, I., Hamzaoui-Azaza, F. and Bouhlila, R., (2016). Application of multivariate statistical analysis and hydrochemical and isotopic investigations for evaluation of groundwater quality and its suitability for drinking and agriculture purposes: case of Oum AliThelepte aquifer, central Tunisia. Environmental monitoring and assessment, 188(3), p.135.

Islam, A.R.M.T., Ahmed, N., Bodrud-Doza, M. and Chu, R., (2017). Characterizing groundwater quality ranks for drinking purposes in Sylhet district, Bangladesh, using entropy method, spatial autocorrelation index and geostatistics. Environmental Science and Pollution Research, 24(34), pp.26350-26374.

Islam, A. R. M. T., Rakib, M. A., Islam, M. S., Jahan, K., \& Patwary, M. A., (2015). Assessment of health hazard of metal concentration in groundwater of Bangladesh. American Chemical Science Journal, 5(1), 41-49.

Islam, A.T., Shen, S., Bodrud-Doza, M., Rahman, M.A. and Das, S., (2017a). Assessment of trace elements of groundwater and their spatial distribution in Rangpur district, Bangladesh. Arabian Journal of Geosciences, 10(4), p.95.

Islam, A.T., Shen, S., Haque, M.A., Bodrud-Doza, M., Maw, K.W. and Habib, M.A., (2017b). Assessing groundwater quality and its sustainability in Joypurhat district of Bangladesh using GIS and multivariate statistical approaches. Environment, Development and Sustainability, pp.1-25.

Islam, M.S. and Shamsad, S.Z.K.M., (2009). Assessment of irrigation water quality of Bogra district in Bangladesh. Bangladesh Journal of Agricultural Research, 34(4), pp.507-608.

Kumari, S., Singh, A.K., Verma, A.K. and Yaduvanshi, N.P.S., (2014). Assessment and spatial distribution of groundwater quality in industrial areas of Ghaziabad, India. Environmental monitoring and assessment, 186(1), pp.501-514.

Masoud, A.A., (2014). Groundwater quality assessment of the shallow aquifers west of the Nile Delta (Egypt) using multivariate statistical and geostatistical techniques. Journal of African Earth Sciences, 95, pp.123-137.

Munna, G.M., Kibriya, N.A., Nury, A.H., Islam, S. and Rahman, H., 2015. Spatial distribution analysis and mapping of groundwater quality parameters for the Sylhet City Corporation (SCC) area using GIS. Hydrology, 3(1), pp.1-10.

Prasad, B. and Bose, J., (2001). Evaluation of the heavy metal pollution index for surface and spring water near a limestone mining area of the lower Himalayas. Environmental Geology, 41(1-2), pp.183-188.

Rahman, M.A.T., Saadat, A.H.M., Islam, M.S., Al-Mansur, M.A. and Ahmed, S., (2017). Groundwater characterization and selection of suitable water type for irrigation in the western region of Bangladesh. Applied Water Science, 7(1), pp.233-243.

Salam, M.A., Othman, F.B., Khan, M.S., Kabir, M.M., R.A. E., Khaleque, M.A., (2019). Assessment of Water Quality and Sedimentary Nutrient Status of Tumpat Mangrove Swamp Forest at Kelantan Delta, Malaysia, Borneo Journal of Sciences and Technology, 1(1), pp. 21-28.

Sarkar, A.A. and Hassan, A.A., (2006). Water quality assessment of a groundwater basin in Bangladesh for irrigation use. Pakistan Journal of Biological Sciences, 9(9), pp.1677-1684.

Shi, J., Wang, H., Xu, J., Wu, J., Liu, X., Zhu, H. and Yu, C., (2007). Spatial distribution of heavy metals in soils: a case study of Changxing, China. Environmental Geology, 52(1), pp.1-10.

Tiwari, A.K., Singh, P.K. and Mahato, M.K., (2014). GIS-based evaluation of water quality index of ground water resources in West Bokaro Coalfield, India. Current World Environment, 9(3), p.843.

WHO, (2011). Guidelines for drinking-water quality, 3rd ed., vol. 1, Recommendations. WHO, Geneva.

Yongming, H., Peixuan, D., Junji, C. and Posmentier, E.S., (2006). Multivariate analysis of heavy metal contamination in urban dusts of Xi'an, Central China. Science of the total environment, 355(1-3), pp.176-186.

Zaman, M.W., Nizam, M.A., Rahman, M.M., (2001). Arsenic and trace element toxicity in groundwater for agricultural, drinking and industrial usage. Bangladesh J. Agric. Res. 26 (3), 167-177. 